\title{
Behavior of Photovoltaic System during Solar Eclipse in Prague
}

\author{
Martin Libra, Pavel Kouřím, and Vladislav Poulek \\ Czech University of Life Sciences Prague, Kamycka 129, 16521 Prague 6, Czech Republic \\ Correspondence should be addressed to Martin Libra; libra@tf.czu.cz
}

Received 4 September 2015; Revised 6 January 2016; Accepted 6 January 2016

Academic Editor: Clito Afonso

Copyright (C) 2016 Martin Libra et al. This is an open access article distributed under the Creative Commons Attribution License, which permits unrestricted use, distribution, and reproduction in any medium, provided the original work is properly cited.

PV power plants have been recently installed in very large scale. So the effects of the solar eclipse are of big importance especially for grid connected photovoltaic (PV) systems. There was a partial solar eclipse in Prague on 20th March 2015. We have evaluated the data from our facility in order to monitor the impact of this natural phenomenon on the behavior of PV system, and these results are presented in the paper. The behavior of PV system corresponds with the theoretical assumption. The power decrease of the PV array corresponds with the relative size of the solar eclipse. $I-V$ characteristics of the PV panel correspond to the theoretical model presented in our previous work.

\section{Introduction}

We have developed and tested a number of PV systems of various structures especially with one ax tracking stand at Faculty of Engineering, the Czech University of Life Sciences Prague. The results were published, for example, in reports [1-3]. We have developed a new generation of PV panels particularly suited to areas with extreme climatic conditions [4]. They are the existing PV systems with two-ax tracking stand; they are described, for example, in the report [5].

On 20th March 2015, there was a partial solar eclipse in Prague, which amounted to a maximum of $68 \%$ coverage of the surface of the solar disc. There was very favorable weather during two consecutive very sunny days. We have had the opportunity to measure and evaluate data on the behavior of PV system during this unique natural phenomenon. These data are presented and discussed below in this paper. Similar data are not found in the literature, so we believe that they are unique. But the behavior of PV systems in artificial shading was tested in some works, for example, [6-9]. There are other models of the partial shading effect in $[10,11]$. The effect of the solar eclipse on grid connected PV power plants was investigated in [12].

In our previous work [13], we have examined the theoretical model of the behavior of $I-V$ characteristics in terms of the theory of semiconductors. The results of our measurement of relevant variables during the solar eclipse presented below confirmed a good agreement of theory and experiment.

\section{Experimental}

The PV system used for the measurement of the time series of instantaneous output power and amount of generated electric energy is shown in Figure 1. Three mono-Si PV panels MOTECH with a nominal power of $170 \mathrm{~W}_{\mathrm{p}}$ are connected in series. The total nominal output power of PV system is therefore $510 \mathrm{~W}_{\mathrm{p}}$. The PV system is oriented to the south at an angle of $45^{\circ}$. The PV panels are connected to the SMA Sunny Boy SB 700 inverter and the output alternating current is connected directly into the public grid. The data are saved automatically.

The radiation intensity and the temperature of PV panels and of the air were measured by the SMA Sunny Sensor Box. Thermometers were based on thermistors. The height and azimuth of the Sun were deduced from the ephemeris and the angle of incidence was calculated as the deviation of the vector directed toward the Sun and of the vector perpendicular to the plane of PV panels. We defined Cartesian coordinates: $x$ : horizontal from west to east, $y$ : vertical from down to up, $z$ : horizontal from north to south. The vector $a=(0,1,1)$ is perpendicular to the PV panels, and the vector $\vec{b}$ directed toward the Sun depends on the actual height and azimuth. 


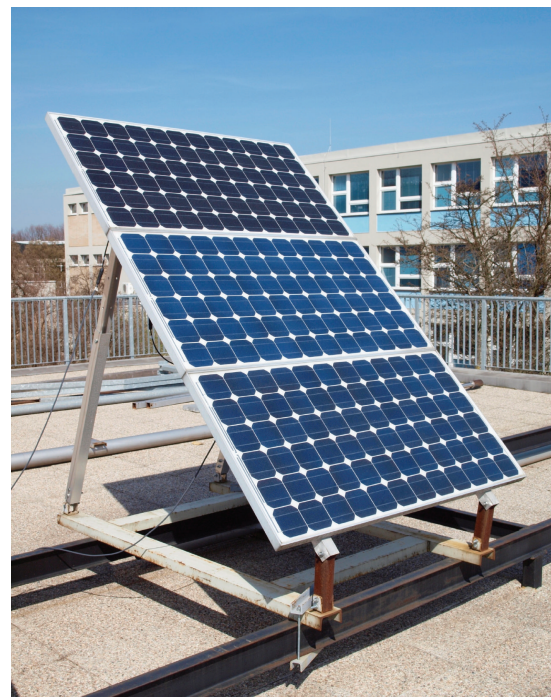

FIGURE 1: Our PV system used for data monitoring during the solar eclipse.

TABLE 1: Selected values of important variables during the solar eclipse on March 20, 2015.

\begin{tabular}{lccccc}
\hline Eclipse phase & $\begin{array}{c}\text { Time } \\
(\mathrm{h})\end{array}$ & $\begin{array}{c}\text { Solar disk coverage } \\
(\%)\end{array}$ & $\begin{array}{c}\text { Sun height } \\
\left({ }^{\circ}\right)\end{array}$ & $\begin{array}{c}\text { Sun azimuth } \\
\left({ }^{\circ}\right)\end{array}$ & $\begin{array}{c}\text { Angle of incidence of sun rays on PV } \\
\text { panels } \\
\left({ }^{\circ}\right)\end{array}$ \\
\hline Start & $9: 37$ & 0 & 30 & 134 & 39 \\
Maximum & $10: 46$ & 68 & 37 & 154 & 21 \\
Finish & $11: 58$ & 0 & 40 & 176 & 5 \\
\hline
\end{tabular}

The following equation $\vec{a} \cdot \vec{b}=|\vec{a}| \cdot|\vec{b}| \cdot \cos \alpha$ is valid for the scalar product. We calculated the deviation $\alpha$ from this equation.

The Yingli $230 \mathrm{~W}_{\mathrm{p}}$ poly-Si PV panel was used for $I-V$ characteristics measurement. The orientation to the south and the angle were identical with the above-mentioned monocrystalline PV panels MOTECH. Characteristics were measured by the semiautomatic device Prova 210 during the eclipse.

\section{Results and Discussion}

Figure 2 shows the Sun at the stage of maximum eclipse, as seen from our university campus. Selected values of important parameters during the solar eclipse are summarized in Tables 1 and 2. The intensity of the incident solar radiation was measured on a horizontal plane. These values were later recalculated on the values corresponding with the plane perpendicular to the sun rays and with the plane of PV panels surface. The recalculation was done by projection of the plane to the plane perpendicular to the sun rays.

Figure 3(a) is a plot of instantaneous power at the time and the amount of electricity produced during two sunny days 19th to 20th March 2015. It is seen that the maximum decrease of the instantaneous power during the eclipse was $-69 \%$ in comparison with the value from the previous day. It excellently corresponds with the coverage area of the solar disc $68 \%$ with regard to the minor differences of

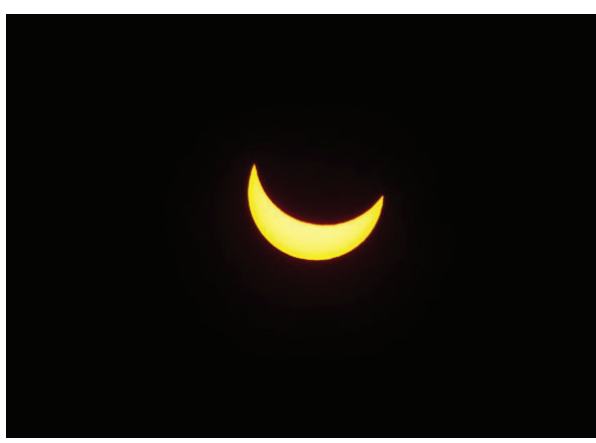

FIGURE 2: Sun in the maximum phase of the eclipse visible from our university campus in Prague.

measurement conditions in two consecutive sunny days. The amount of generated electric energy corresponds with the area under the graph curve. It is lower by about $13.5 \%$ in the eclipse day.

Figure 3(b) shows the corresponding dependences of the solar radiation intensity incident on a horizontal plane. However, the graphs in Figure 3 cannot be accurately compared, because the angle of incidence of sun rays on horizontal plane varies with the time a bit differently compared to the angle of incidence on the surface of the PV panels with an inclination towards south (see Table 2). 
TABLE 2: Selected values of important variables during the solar eclipse on March 20, 2015.

\begin{tabular}{|c|c|c|c|c|c|c|}
\hline Eclipse phase & $\begin{array}{l}\text { Time } \\
\text { (h) }\end{array}$ & $\begin{array}{l}\text { Solar radiation intensity } \\
\text { on horizontal plane } \\
\left(\mathrm{W} \cdot \mathrm{m}^{-2}\right)\end{array}$ & $\begin{array}{c}\text { Solar radiation } \\
\text { intensity on } \\
\text { perpendicular plane } \\
\left(\mathrm{W} \cdot \mathrm{m}^{-2}\right)\end{array}$ & $\begin{array}{l}\text { Solar radiation intensity } \\
\text { on } \mathrm{PV} \text { panels } \\
\left(\mathrm{W} \cdot \mathrm{m}^{-2}\right)\end{array}$ & $\begin{array}{c}\text { Temperature of PV } \\
\text { panels } \\
\left({ }^{\circ} \mathrm{C}\right)\end{array}$ & $\begin{array}{l}\text { Instantaneous } \\
\text { output power } \\
\text { (W) }\end{array}$ \\
\hline Start & $9: 37$ & 437 & 874 & 679 & 31 & 340 \\
\hline Maximum & $10: 46$ & 155 & 258 & 241 & 14 & 124 \\
\hline Finish & $11: 58$ & 612 & 952 & 948 & 43 & 415 \\
\hline
\end{tabular}

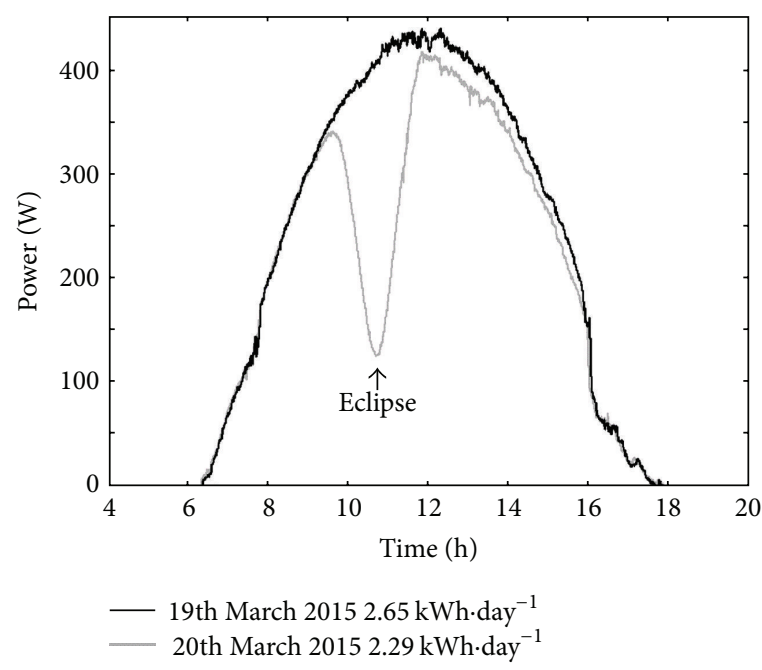

(a)

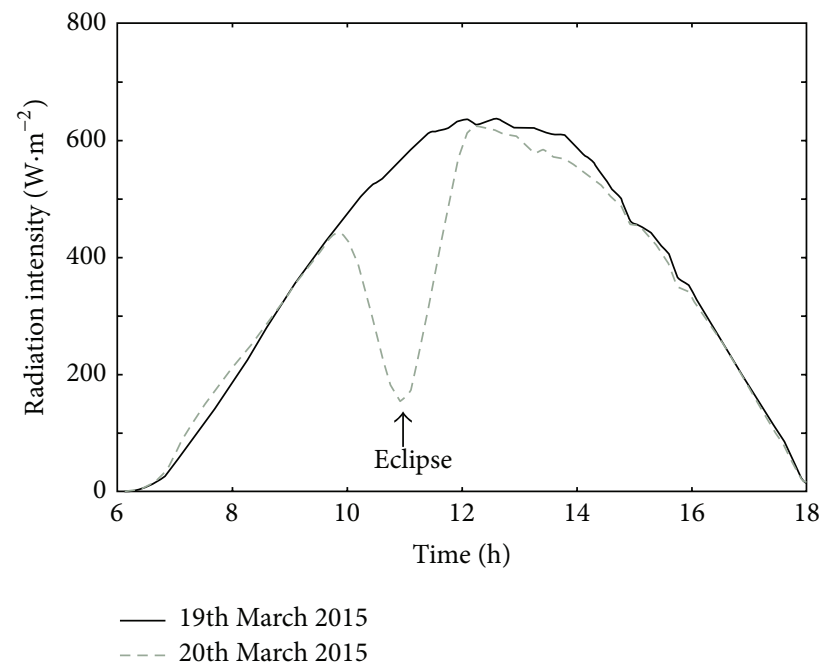

(b)

Figure 3: (a) Time series of instantaneous output power and the amount of generated electric energy and (b) time series of solar radiation intensity incident on a horizontal plane, during two sunny days (19th to 20th March 2015).

Figure 4 shows dependences of PV panels temperature, air temperature, and wind speed on the time during both monitored days. The decrease of the air temperature and of the PV panels temperature during a solar eclipse is seen, which is related to the decrease in the intensity of radiation (see Table 2). Moreover, on 19th March 2015 noon, mild local minimum of temperature related to the higher wind speed and thus to more intense cooling of the PV panels is seen (see Figure 4(b)). Conversely, on 20th March 2015 around noon, after the solar eclipse, the air temperature and PV panels temperature showed maximum, because the wind speed was lower than at noon the previous day. On 20th March 2015, the wind speed was increased after the 13th hour and then also the temperature of PV panels began to decrease.

Figure 5 shows the $I-V$ characteristics of the PV panel measured at different stages of the eclipse. It is obvious that their behavior accurately corresponds to theoretical model published in [13] and/or for instance [14, 15]. The open circuit voltage is reduced at higher temperature of PV panel. It is associated with a shift of the Fermi energy level $E_{F}$ toward the center of the forbidden gap in a band diagram of energy levels in the semiconductor (see Figure 6). This leads to a reduction in potential barrier of the $\mathrm{PN}$ junction. The higher radiation intensity causes higher short-circuit current due to higher generation of free electrons and holes. It coincides well with the theory of semiconductors.
Solar eclipse is then reflected in the energy sector on a wider scale. Total eclipse has on the Earth's surface the area of a circle with a diameter of about $200 \mathrm{~km}$ and it is moving. The entire eclipse process takes about $2.5 \mathrm{~h}$ from the beginning to the end. On a much larger area, there is a partial eclipse. On an area corresponding to the total eclipse, in some countries (especially in Europe, including Germany, Czech Republic, etc.), the installed nominal power of PV power plants is in the range $\approx 1000 \mathrm{MW}_{\mathrm{p}}$. The installed nominal output power is even much higher on the area of partial eclipse. Figure 3(a) shows that the absolute value of the maximum derivative of the power curve by the time is corresponding to a decrease (and later increase) in the instantaneous power of about $0.1 \mathrm{~W} \cdot \mathrm{s}^{-1}$. For PV system with a nominal output of $510 \mathrm{~W}$, it represents $0.02 \% \cdot \mathrm{s}^{-1}$. Thus, if PV power plants with the nominal output power of $1,000 \mathrm{MW}_{\mathrm{p}}$ are installed on the said area, on a sunny day, there would be maximum power decrease rate (and later increase rate) $0.2 \mathrm{MW} \cdot \mathrm{s}^{-1}$ in the local grid during the total eclipse.

\section{Conclusion}

Thanks to the favorable weather on 19th to 20th March 2015, we were able to observe the behavior of PV system during the solar eclipse. Monitoring of the data during two 

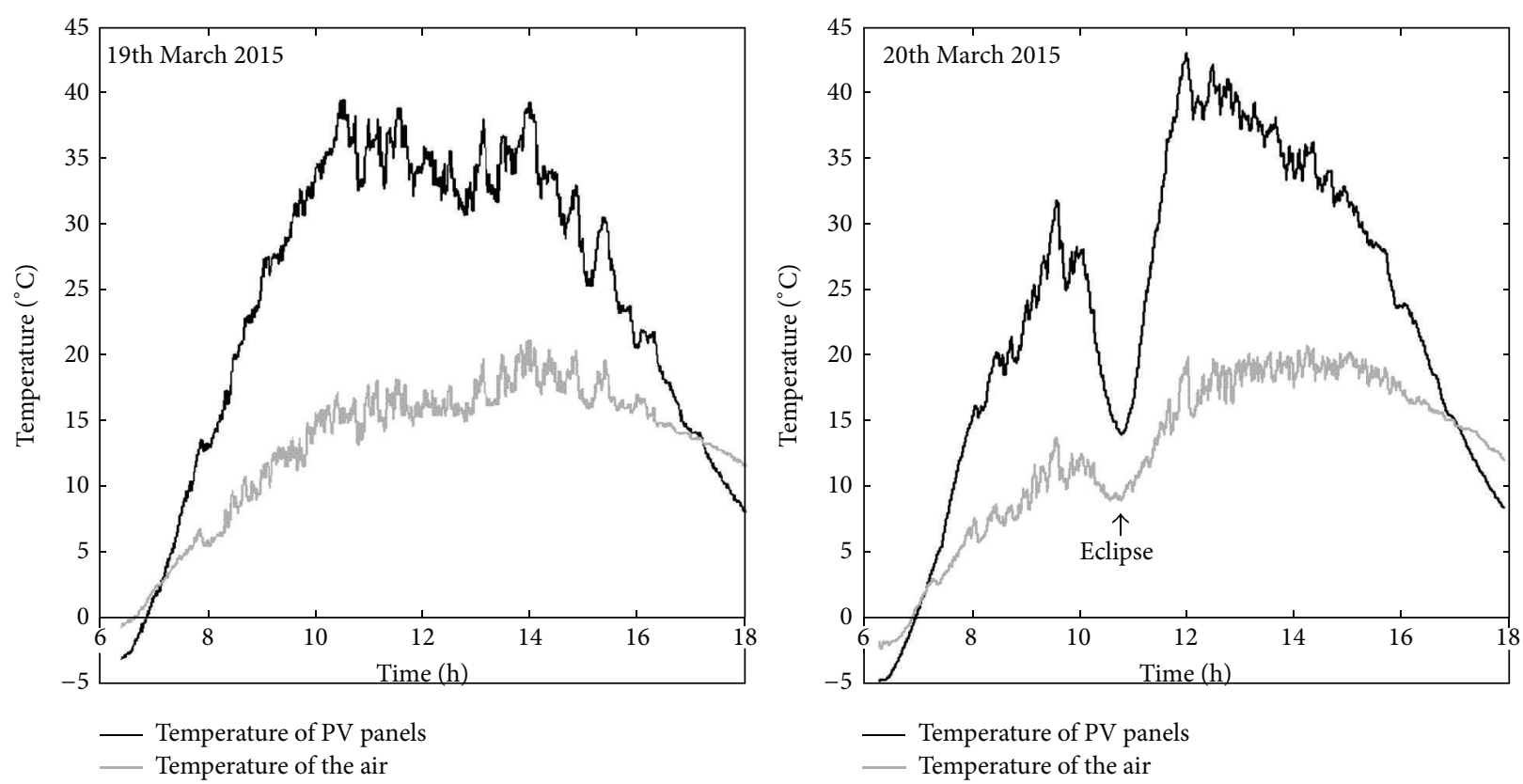

(a)
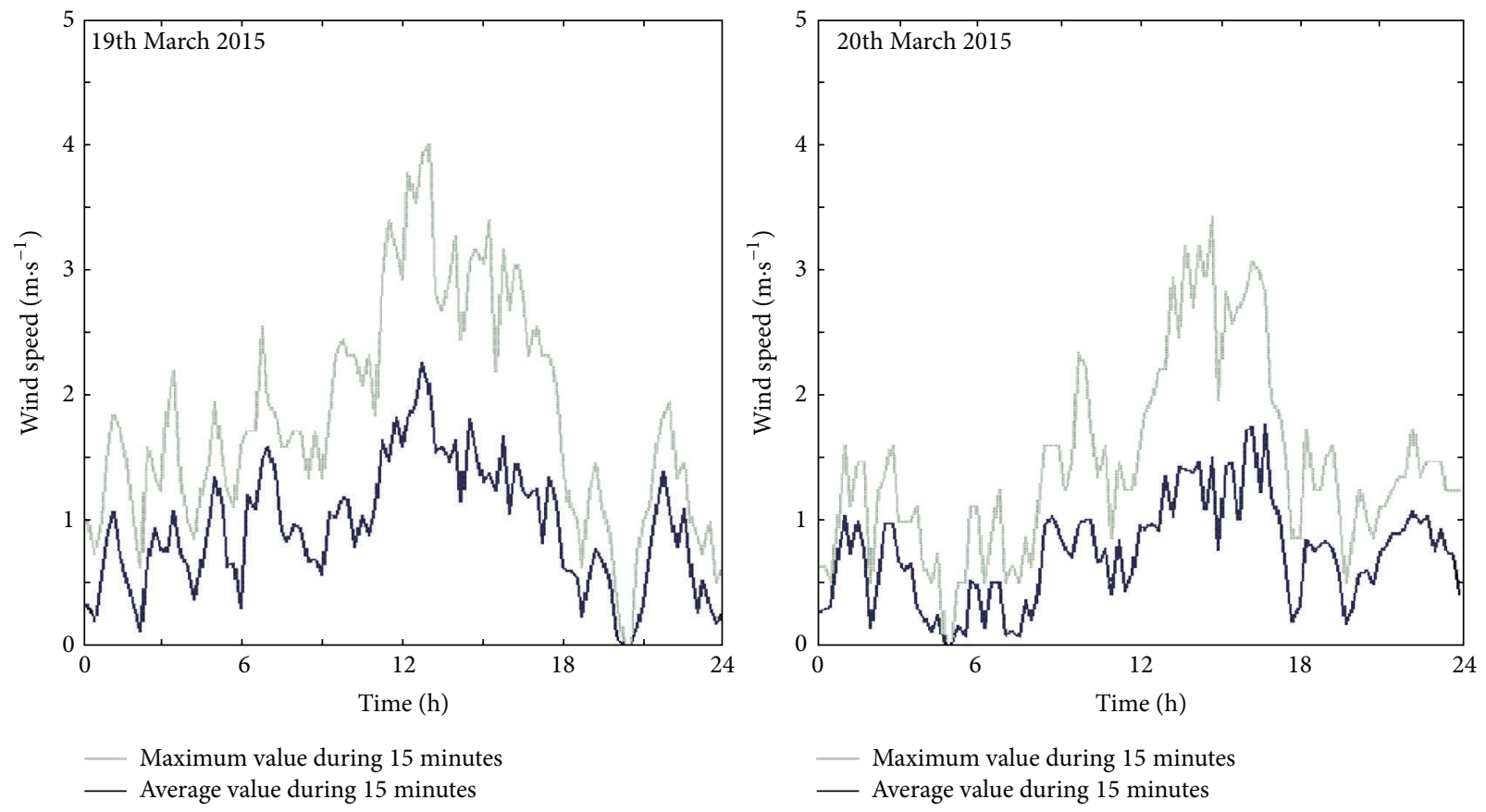

(b)

Figure 4: (a) Time series of PV panels temperature and air temperature and (b) time series of wind speed, during two sunny days (19th to 20th March 2015).

consecutive sunny days, including the solar eclipse, shows excellent agreement of theory and experiment.

(i) Decrease of the instantaneous output power of the PV system during the solar eclipse corresponds with the relative shading of the solar disc and with decrease of the intensity of solar radiation.

(ii) A lower value of instantaneous output power after the eclipse may be associated with the condensation of water vapor in atmosphere due to the decrease of 


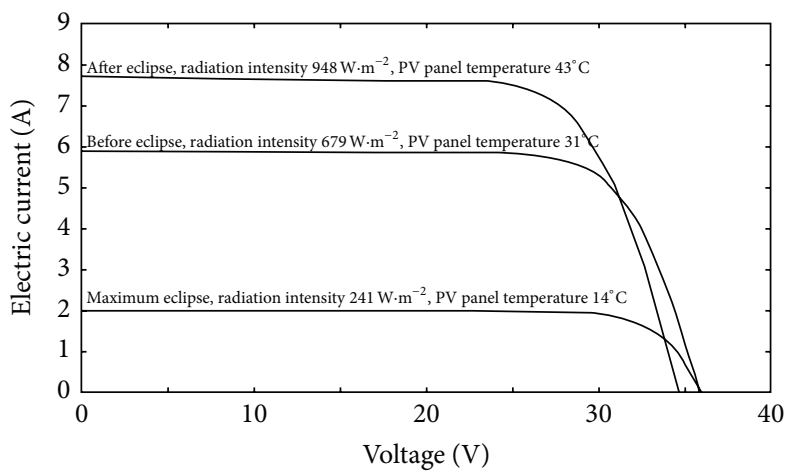

FIGURE 5: $I-V$ characteristics of the Yingli $230 \mathrm{~W}_{\mathrm{p}}$ poly-Si PV panel in various stages of eclipse.

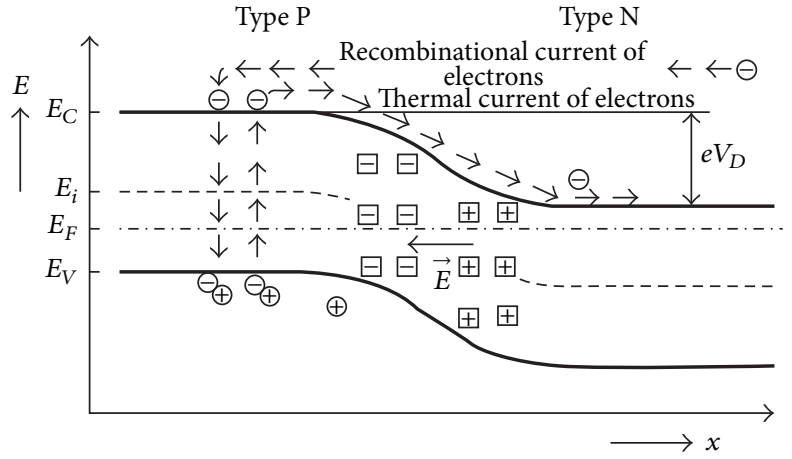

(a)

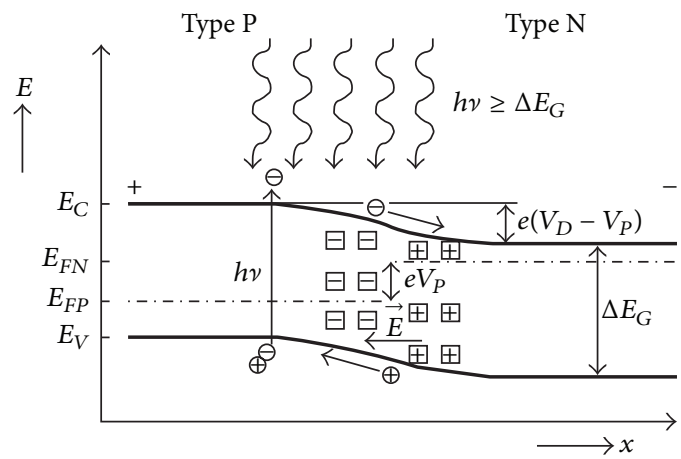

(b)

Figure 6: Band diagram of energy levels of the PN junction: (a) not illuminated, (b) illuminated ( $E_{F}$ : Fermi energy level, $E_{i}$ : center of the forbidden gap, $E_{V}$ : valence band edge, $E_{C}$ : conduction band edge, $\Delta E_{G}$ : energy forbidden gap, $V_{D}$ : diffusion voltage, $V_{P}$ : photovoltaic voltage, $\vec{E}$ : electric field intensity, $v$ : frequency, $h$ : Planck constant, and $x$ : coordinate perpendicular to the PN junction).

air temperature during eclipse and with the higher absorption in the near infrared region of the spectrum.

(iii) Temperature of PV panels corresponds mainly with the radiation intensity, but it is also influenced by the wind speed and therefore by natural cooling.

(iv) Behavior of $I-V$ characteristics of $\mathrm{PV}$ panel corresponds with the theoretical model based on the theory of semiconductors.

(v) Solar eclipse has a significant impact on the energy sector of some countries focused on renewable energy sources. The drop in performance PV power plants have to be balanced and covered from other sources.

\section{Conflict of Interests}

The authors declare that there is no conflict of interests regarding the publication of this paper.

\section{Acknowledgment}

The work was supported by Internal Research Project, Faculty of Engineering, Czech University of Life Sciences.

\section{References}

[1] V. Poulek and M. Libra, "New solar tracker," Solar Energy Materials and Solar Cells, vol. 51, no. 2, pp. 113-120, 1998.

[2] V. Poulek and M. Libra, "A new low-cost tracking ridge concentrator," Solar Energy Materials and Solar Cells, vol. 61, no. 2, pp. 199-202, 2000.

[3] M. Libra, P. Sedláček, J. Mareš, and V. Poulek, "Porovnání PV systémů s pevným a proměnným sklonem PV panelů," Jemná Mechanika a Optika, vol. 55, no. 10, pp. 270-271, 2010 (Czech).

[4] V. Poulek, D. S. Strebkov, I. S. Persic, and M. Libra, “Towards 50 years lifetime of PV panels laminated with silicone gel technology," Solar Energy, vol. 86, no. 10, pp. 3103-3108, 2012.

[5] R. Gregor, Y. Takase, J. Rodas, L. Carreras, D. Gregor, and A. López, "Biaxial solar tracking system based on the MPPT approach integrating ICTs for photovoltaic applications," International Journal of Photoenergy, vol. 2015, Article ID 202986, 10 pages, 2015.

[6] I. Reda, "Solar eclipse monitoring for solar energy applications," Solar Energy, vol. 112, pp. 339-350, 2015.

[7] P. Kofinas, A. I. Dounis, G. Papadakis, and M. N. Assimakopoulos, "An Intelligent MPPT controller based on direct neural control for partially shaded PV system," Energy and Buildings, vol. 90, pp. 51-64, 2015. 
[8] E. Karatepe, M. Boztepe, and M. Çolak, "Development of a suitable model for characterizing photovoltaic arrays with shaded solar cells," Solar Energy, vol. 81, no. 8, pp. 977-992, 2007.

[9] J.-C. Wang, Y.-L. Su, K.-C. Kuo, J.-C. Shieh, and J.-A. Jiang, "Toward multiple maximum power point estimation of photovoltaic systems based on semiconductor theory," Progress in Photovoltaics: Research and Applications, vol. 23, no. 7, pp. 847861, 2014.

[10] Y. J. Wang and R. L. Sheu, "Probabilistic modeling of partial shading of photovoltaic arrays," International Journal of Photoenergy, vol. 2015, Article ID 863637, 10 pages, 2015.

[11] W. He, F. Liu, J. Ji, S. Zhang, and H. Chen, "Safety analysis of solar module under partial shading," International Journal of Photoenergy, vol. 2015, Article ID 907282, 8 pages, 2015.

[12] C. Köhler, H. Ruf, A. Steiner, D. Lee, J. Thieler, and M. Casel, "Nutzung Numerischer Wettervorhersagen in der Simulation von Verteilnetzen: Die Effekte einer Sonnenfinsternis auf netzgekoppelte PV-Anlagen und Netztransformatoren," in 30th Symposium Photovoltaische Solarenergie, Bad Staffelstein, Germany, March 2015, https://www.researchgate.net/publication/ 273143752_Nutzung_Numerischer_Wettervorhersagen_in_der_ Simulation_von_Verteilnetzen_Die_Effekte_einer_Sonnenfinsternis_auf_netzgekoppelte_PV-Anlagen_und_Netztransformatoren.

[13] V. Poulek and M. Libra, Photovoltaics, ILSA, Prague, Czech Republic, 2010.

[14] M. Barukčić, Ž. Hederić, and Ž. Špoljarić, "The estimation of I-V curves of PV panel using manufacturers' I-V curves and evolutionary strategy," Energy Conversion and Management, vol. 88, pp. 447-458, 2014.

[15] C. Carrero, D. Ramírez, J. Rodríguez, and C. A. Platero, "Accurate and fast convergence method for parameter estimation of PV generators based on three main points of the $I-V$ curve," Renewable Energy, vol. 36, no. 11, pp. 2972-2977, 2011. 

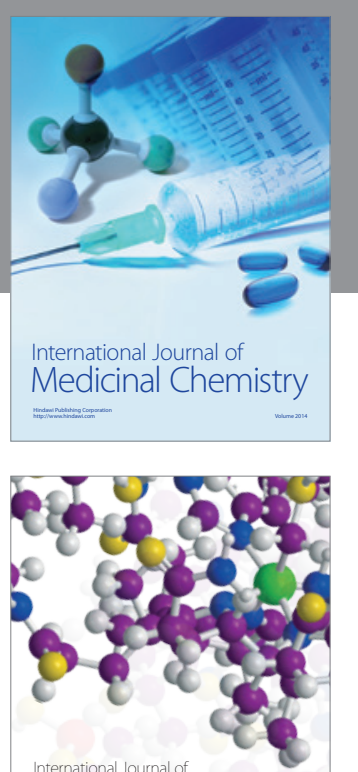

Carbohydrate Chemistry

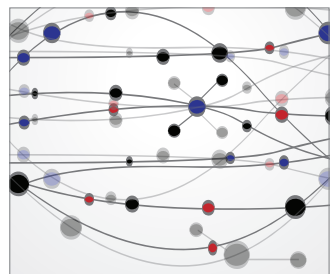

The Scientific World Journal
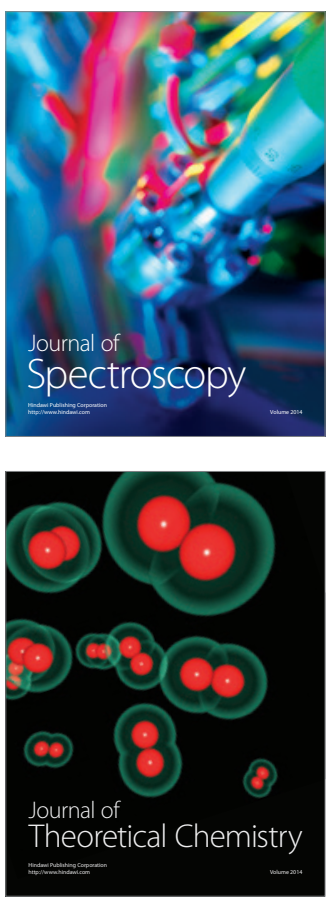
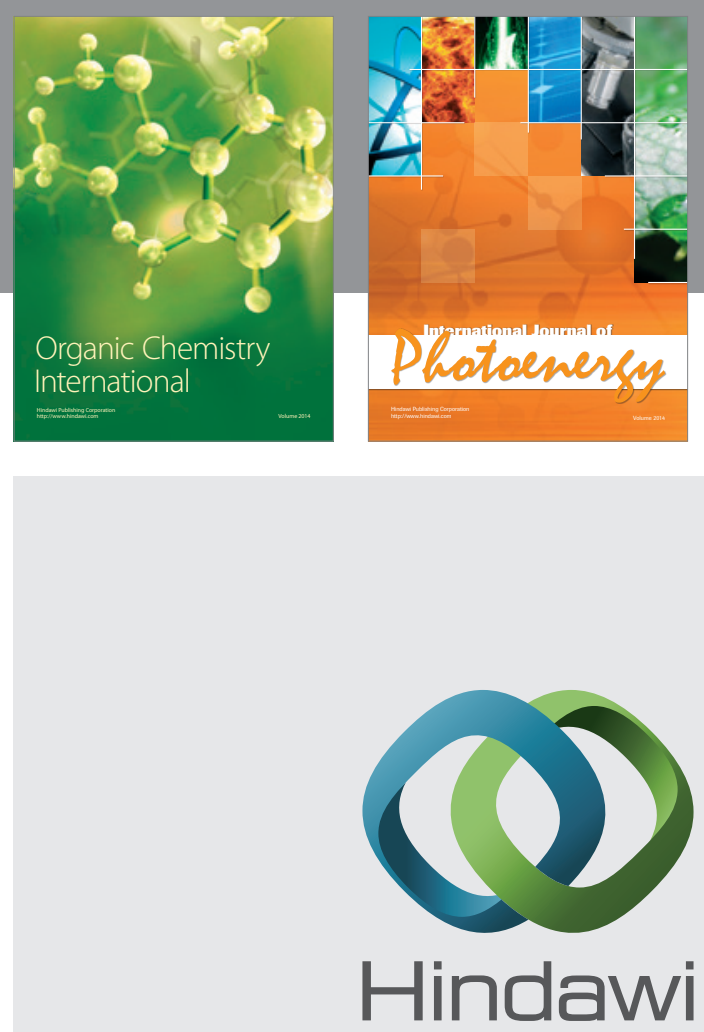

Submit your manuscripts at

http://www.hindawi.com

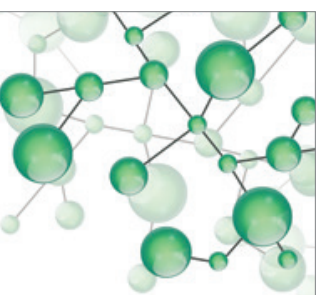

International Journal of

Inorganic Chemistry

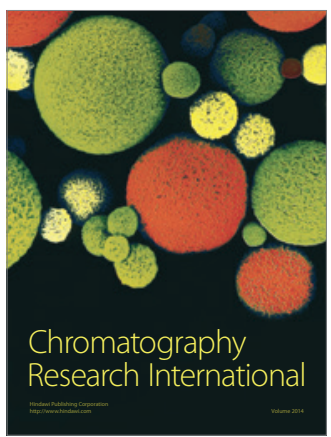

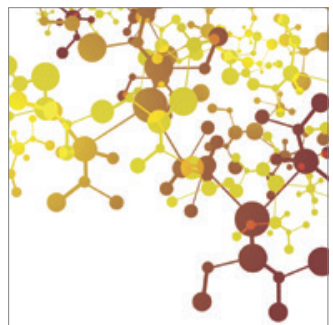

Applied Chemistry
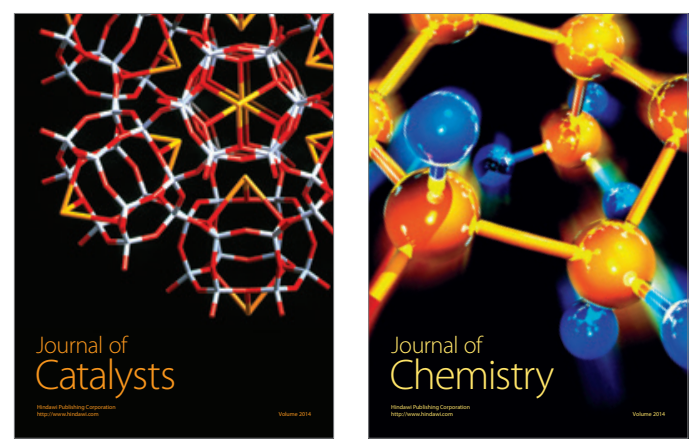
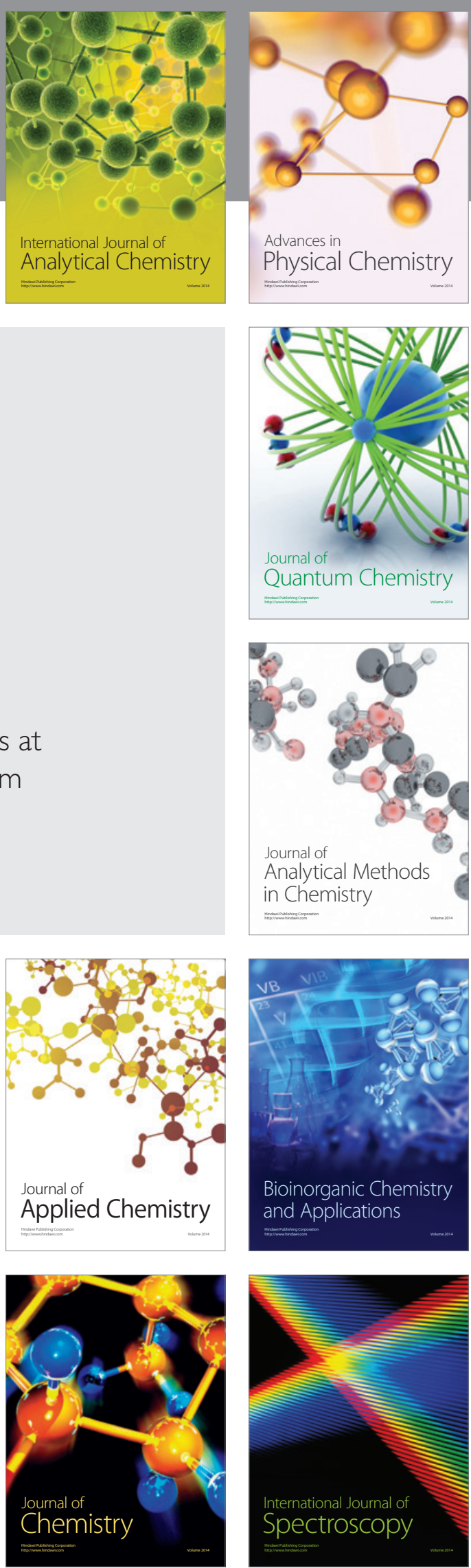